\title{
TEXTOS
}

\section{Poemas de Mary Yiosi}

\section{Cielo bajo y otros poemas 2006}

\section{Cielo bajo}

Lo que sucede

en el ensueño sucede

Por eso no digas

Que un jardín es la estatua

sol el día

Solamente contiene la luz.

Ven laudatorio silencio

Amor que eres un jardín y una prenda

Ven conocimiento que amor eres.

\section{SEIS POEMAS 1995}

\section{Las fuentes de mi riqueza}

Viene una lluvia de aquellas

que embravecen los ríos

Junto manzanas en el delantal

Frutos desconocidos

Hago sangrar los labios.

En las fragancias hundo mis cabellos

Hojas que se lleva el viento

Atardece

Y estoy hasta los tobillos

en la tierra.

Escucho los otros ríos. 
Por entre los árboles

han bajado los pájaros

Con la lluvia me tienden cielo

Para que yo pise.

La casa es una lejana

Luz.

\section{SIN TÍTULO 1995}

\begin{tabular}{|c|}
\hline $\begin{array}{l}\text { Instantáneo el cuerpo } \\
\text { sobre el cual se posa } \\
\text { melodiosa mariposa } \\
\text { mi voz }\end{array}$ \\
\hline $\begin{array}{l}\text { (Tiene puertas la noche } \\
\text { tiernas para los cuerpos) }\end{array}$ \\
\hline
\end{tabular}

En el agua verde oscuro enroscada la imagen

-Dentro del agua el sonido

todavía ahogado -

Tiene algo de la muerte de la forma que poseía.

Igualmente a veces el amor.

VI

Testigo sea mi lengua

de todo lo indecible.

¿Lo azulado dirás o lo violeta

el intenso púrpura hacia el poniente

o el negro oscuro que traza línea

en toda la superficie de los colores? 


\section{IX}

Su caballo

-sus pezuñas en la nieve-

La nieve

-su negro blanco-

La noche.

\section{VIAJES 1999-2002}

\section{El viajero}

Con la maleta en la mano

El viajero

$\mathrm{Ni}$ viene

$\mathrm{Ni}$ se va.

De su corazón

Falta el minutero

Las horas lentamente pasan

Porque impacientemente

El viajero

ni se viene ni se va.

\section{Segunda voz}

Tiene el alma tristeza. Cual gavillas de tabaco

Sus viejas palabras. Los indescriptibles paisajes.

Un pequeño ciervo sacia su sed en los sueños.

Más asustado.

No señales. No hables. Solamente sé tú. 


\section{LAS PALABRAS VIEJAS}

Sangre oscura

Se rompe la danza de las palabras.

$*$

La gente se reparte

en reuniones

Rodajas de silencio

el instantáneo universo.

Y un pájaro, pájaro negro

con pasión mi sueño abraza.

\section{EL MUNDO DE LAS COSAS SENSIBLES 1985}

Una mujer es

un rostro en la ventana.

Cada hombre

una voz encerrada

busca florecer

florece a menudo

Un hombre es lo que teme. 